\title{
Coordinate Secretion of Acid Hydrolases in Rat Bile
}

\author{
HEPATOCYTE EXOCYTOSIS OF LYSOSOMAL PROTEIN?
}

\author{
Nicholas F. LARUSSO and STANLEy Fowler, The Rockefeller University, \\ New York 10021
}

\begin{abstract}
A B S T RACT Three lysosomal glycosidases, $\beta$-glucuronidase (EC 3.2.1.31), $\beta$-galactosidase (EC 3.2.1.23), and $N$-acetyl- $\beta$-glucosaminidase (EC 3.2.1.30) have been investigated in bile that was freshly collected from rats through a complete bile fistula. Assay conditions have been established on the basis of appropriate kinetic studies. The biliary excretion patterns for these enzymes were found to vary considerably from rat to rat during the 24 -h collection period. In a given animal, however, the three hydrolases were excreted in parallel and showed a gradual increase in activity with time, most marked after 10-12 h of collection. 24-h biliary outputs of the three hydrolases averaged $\cong 3 \%$ of their respective contents in total liver, and bile diversion had no effect on hepatic glycosidase activity or total protein content. Other enzymes known to be associated primarily with mitochondria, endoplasmic reticulum, and cell sap were also detected in bile, generally in smaller amounts. The biliary excretion of the plasma membrane markers, alkaline phosphodiesterase I and 5 '-nucleotidase, however, was comparable to that of the lysosomal hydrolases. Biliary excretion of total protein was relatively constant and corresponded to $3.0 \%$ of the total hepatic protein content per day, whereas biliary bile acid secretion decreased during the first $12 \mathrm{~h}$ and then remained constant. Exocytic bulk discharge of hepatocyte lysosomes is proposed as the most likely mechanism for the biliary excretion of lysosomal enzymes. These results call attention to the possible pathophysiologic significance of biliary excretion of hepatic lysosomal contents as a means of residue disposal.
\end{abstract}

A preliminary report of part of this work appeared in 1977. Gastroenterology. 73: A32/1230. (Abstr.)

Dr. LaRusso is a Mayo Foundation Scholar and a George Morris Piersol Teaching and Research Scholar of the American College of Physicians. His present address is: Gastroenterology Unit, Mayo Clinic \& Foundation, Rochester, Minn. 55901. Dr. Fowler is an Otto G. Storm Investigator of the American Heart Association.

Received for publication 13 November 1978 and in revised form 22 May 1979.

\section{INTRODUCTION}

In 1966, de Duve and Wattiaux proposed the hypothesis that "extrusion in bile is the major pathway of unloading of the lysosomes of hepatic parenchymal cells" (1). This hypothesis was based on suggestive morphologic evidence (2) and on unpublished preliminary biochemical data by Wattiaux. With electron microscopy, endogenous ferritin (3) and injected particles of colloidal gold (4) can be seen within both hepatocyte lysosomes and biliary canaliculi. Also, several reports have described acid hydrolase activity in bile (5-7). Thus, whereas no systematic study has quantitatively and qualitatively evaluated the biliary excretion of lysosomal protein, there are data suggesting its occurrence.

In these studies, we demonstrate the presence of a variety of enzymes, including lysosomal acid hydrolases, in bile from bile-fistula rats. After establishing quantitative fluorometric assays for measurements in bile of the three lysosomal enzymes, $\beta$-glucuronidase (EC 3.2.1.31), $\beta$-galactosidase (EC 3.2.1.23), and $N$ acetyl- $\beta$-glucosaminidase (EC 3.2.1.30), we determined their biliary output relative to total biliary protein and bile acids. Our findings indicate that $\cong 3 \%$ of the total liver content of these enzymes may be excreted in a 24-h period. More importantly, the enzymes appear to be discharged coordinately.

Our data suggest that lysosomal enzymes undergo parallel biliary excretion by a specific mechanism probably independent of bile acid secretion. Our data are also consistent with the hypothesis of hepatocyte exocytosis of lysosomal contents.

\section{METHODS}

General experimental procedure. Male Sprague-Dawley rats $(150-300 \mathrm{~g})$ were used for all experiments. Animals were fed Purina Laboratory Chow (Ralston Purina Co., St. Louis, Mo.) and were permitted access to food and water until $24 \mathrm{~h}$ before each study. A complete bile fistula was prepared under ether anesthesia at $0700 \mathrm{~h}$, and rats were placed in restraining cages for the duration of each experiment (8). After a 2-h equilibration period to allow recovery from surgery and anesthesia, 
bile was collected on ice for $24 \mathrm{~h}$ into preweighed tubes at 2-h intervals for $12 \mathrm{~h}$ and then at 8 - to 12 -h intervals. The volumes of collected samples were determined by weight, assuming a density for bile of $1.0 \mathrm{~g} / \mathrm{ml}$. During the study, nothing was given to the animals by mouth, but $0.9 \% \mathrm{NaCl}$ was administered through a tail vein at $1.7 \mathrm{ml} / \mathrm{h}$. In most experiments, enzyme activities in the liver were determined at the end of the 24-h collection period. Rats were killed by exsanguination, and their livers were quickly removed and immersed in icecold 250-mM sucrose. $6 \mathrm{~g}$ of liver from each animal was homogenized in $18 \mathrm{ml}$ of $250-\mathrm{mM}$ sucrose with three strokes of a Potter-Elvejhem homogenizer (Kontes Glass Co., Vineland, N. J.) and then centrifuged at low speed (1,500 rpm for $10 \mathrm{~min})$ to separate nuclei, unbroken cells, and tissue debris (pellet or $\mathrm{N}$-fraction, diluted to $1 \mathrm{~g}$ of equivalent liver in $5 \mathrm{ml}$ of sucrose) from other intact organelles and cell sap (supernate or E-fraction, diluted to $1 \mathrm{~g}$ of equivalent liver in $10 \mathrm{ml}$ of sucrose) as described (9). Analytical studies were performed on aliquots of bile or liver $\mathrm{E}$ - and $\mathrm{N}$-fractions suitably diluted in sucrose. Values for total liver were calculated as the sum of the activities found in the $\mathrm{E}$ - and $\mathrm{N}$-fractions.

Analytical Procedures. Glycosidases were assayed fluorometrically by use of 4-methyl umbelliferyl substrates (KochLight Laboratories, Ltd., Colnbrook, Buckinghamshire, England) as described by Peters et al. (10). Stock solutions of substances $(10 \mathrm{mM})$ were prepared in moisture-free methoxyethanol and stored at $4^{\circ} \mathrm{C}$. The compositions of the substrate mixtures used for each of the assays were as follows: $\beta$-glucuronidase: $0.5 \mathrm{mM} 4$-methyl umbelliferyl- $\beta$-D-glucuronide, $0.02 \%$ bovine serum albumin, $10 \mathrm{mM}$ EDTA, $0.2 \%$ Triton X-100 (Rohm and Haas Co., Philadelphia, Pa.), and 100 $\mathrm{mM} \mathrm{Na}$ acetate, $\mathrm{pH} 4.4 ; \beta$-galactosidase: $0.5 \mathrm{mM}$ 4-methyl umbelliferyl- $\beta$-D-galactopyranoside, $20 \mathrm{mM} \mathrm{MgCl}_{2}, 0.2 \%$ Triton X-100, and $100 \mathrm{mM} \mathrm{Na}$ formate, $\mathrm{pH} 3.8 ; N$-acetyl- $\beta$ glucosaminidase: $0.5 \mathrm{mM}$ 4-methyl umbelliferyl-2-acetoamido-2-deoxy- $\beta$-D-glucopyranoside, $0.2 \%$ Triton $\mathrm{X}-100$, and $100 \mathrm{mM}$ Na citrate, $\mathrm{pH} 4.5$. A $0.1-\mathrm{ml}$ aliquot of bile or tissue sample was incubated at $37^{\circ} \mathrm{C}$ for $10-45 \mathrm{~min}$ with $0.1 \mathrm{ml}$ of the appropriate substrate mixture. The reaction was stopped by rapid addition of $2 \mathrm{ml}$ of $50-\mathrm{mM} \mathrm{NaOH}$-glycine buffer, $\mathrm{pH}$ 10.4, which contained $5 \mathrm{mM}$ EDTA. The liberated 4-methyl umbelliferone was measured in a Perkin-Elmer fluorescence spectrophotometer (model 203 with Xenon lamp; PerkinElmer Corp., Norwalk, Conn.) with excitation and emission wavelengths set at 365 and $460 \mathrm{~nm}$, respectively. Substrate and enzyme blanks were incubated and treated in the same manner. Quantitation of fluorescence was determined by mixing known concentrations of 4-methyl umbelliferone in the appropriate buffer with $2 \mathrm{ml}$ of the $\mathrm{NaOH}$-glycine stopping solution and measuring the amount of fluorescence as described above.

Esterase was measured by following, at $420 \mathrm{~nm}$, the produc-

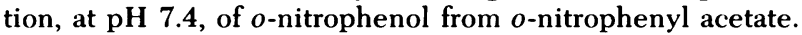
Alkaline phosphodiesterase I was assayed at pH 9.6 with $p$ nitrophenyl-thymidine 5 '-phosphate as substrate. Both assays were done employing the incubation conditions reported for rat liver homogenates by Beaufay et al. (11).

5 '-Nucleotidase was assayed in Tris- $\mathrm{HCl}$ buffer, $\mathrm{pH}$ 9.0, with $\left[2{ }^{3} \mathrm{H}\right] \mathrm{AMP}$ as substrate as described by Avruch and Wallach (12). Malate dehydrogenase was determined from the rate of oxidation of NADH measured at $340 \mathrm{~nm}$ in the presence of $c i s$ oxalacetic acid under the conditions described by Dupourque and Kun (13). Lactate dehydrogenase was similarly measured at $\mathrm{pH} 7.4$ after the addition of NADH and pyruvate (14). Suitable enzyme (especially for bile samples) and substrate blanks were carried out for all assays.

Protein determinations on samples were done by an automated Lowry procedure (15). Total bile acids were measured by the 3-steroid dehydrogenase method of Iwata and Yamasaki (16) with minor modification.

For all hydrolases, $1 \mathrm{U}$ of activity corresponds to the hydrolysis of $1 \mu \mathrm{mol}$ substrate/min. Dehydrogenase activities are expressed as the micromoles of NADH oxidized per minute.

\section{RESULTS}

Survey of enzyme activity in bile. The activity of enzymes known to be associated with a variety of subcellular organelles is shown in Table I for both bile and liver taken from four rats after an overnight fast. Activity of all enzymes was detected in bile, but there were considerable differences in the levels of activity. If the ratio of enzyme activity in bile to liver is expressed as percentage of total liver activity excreted during the 4-h collection period, the lysosomal and plasma membrane enzymes have greater activities than the other enzymes studied. By paired $t$ test, these differences were significant $(P<0.05)$ for lysosomal vs. mitochondrial and cell sap enzymes, and nearly significant $(0.10<P>0.05)$ for lysosomal vs. a single endoplasmic reticulum enzyme. Detailed studies of enzyme kinetics in bile were performed only for the glycosidases (next section), but for all enzymes listed no significant inhibition of hepatic activities occurred when liver E-fractions were mixed with neat bile or bile diluted only twofold.

Properties and kinetics of the biliary acid glycosidases. To establish valid assay conditions for each of the glycosidases selected for study, experiments were performed to explore variables such as enzyme concentration, incubation time, $\mathrm{pH}$, storage temperature, and effects of bile acids. As shown in Fig. 1, the assay conditions adopted for $\beta$-glucuronidase, $\beta$-galactosidase, and $N$-acetyl- $\beta$-glucosaminidase gave the linearity of activity with time and enzyme concentration required for a quantitative assay. Experiments were performed to determine the influence of $\mathrm{pH}$ on the activities of the same three glycosidases in both liver and bile. An acid $\mathrm{pH}$ optimum was found for each, and the curves were not different for liver or bile samples. Studies on the effect of temperature on activity of the three glycosidases in bile showed that, after incubation of bile at $37^{\circ} \mathrm{C}$ for $2 \mathrm{~h}$, there was a $40 \%$ decrease in activity of $N$-acetyl- $\beta$-glucosaminidase, a $20 \%$ decrease in activity of $\beta$-galactosidase, and no difference in activity of $\beta$-glucuronidase. Activity of all three enzymes did not change over $24 \mathrm{~h}$ if bile was either kept on ice or repeatedly frozen and thawed. Fig. 2 shows the effect of different concentrations of bile on activity of the three enzymes in liver. There was no significant or consistent inhibition of hepatic enzyme activity by bile taken within either the 1st or 24th h of bile collection. However, if aliquots of liver E-fractions were preincubated for $30 \mathrm{~min}$ at $37^{\circ} \mathrm{C}$ with bile that contained different amounts of total bile acids (Table II), there 
TABLE I

Survey of Enzyme Activities in Rat Bile and Liver

\begin{tabular}{llccc}
\hline \multicolumn{1}{c}{ Enzyme } & \multicolumn{1}{c}{ Associated organelle } & Bile* & Livert & $\begin{array}{c}\text { Percentage } \\
\text { of total liver } \\
\text { activity excreted } \\
\text { in bile in } 4 \text { h }\end{array}$ \\
\hline Malate dehydrogenase & Mitochondrion & $30.4 \pm 21$ & $312 \pm 148$ & $0.0013 \pm 0.001$ \\
Esterase & Endoplasmic reticulum & $543 \pm 173$ & $112 \pm 82$ & $0.095 \pm 0.1$ \\
$\beta$-Glucuronidase & Lysosome & $35.3 \pm 21$ & $1.21 \pm 0.08$ & $0.29 \pm 0.2$ \\
$\beta$-Galactosidase & & $9.90 \pm 4.4$ & $0.455 \pm 0.03$ & $0.22 \pm 0.1$ \\
N-acetyl- $\beta$-glucosaminidase & & $31.0 \pm 21$ & $0.797 \pm 0.11$ & $0.41 \pm 0.3$ \\
$5^{\prime}$-Nucleotidase & & $160 \pm 94$ & $3.33 \pm 1.6$ & $0.69 \pm 0.6$ \\
Alkaline phosphodiesterase I & Plasma membrane & $218 \pm 62$ & $19.2 \pm 4.8$ & $0.12 \pm 0.05$ \\
Lactic dehydrogenase & Cell sap & $156 \pm 86$ & $261 \pm 127$ & $0.0071 \pm 0.004$ \\
\hline
\end{tabular}

Complete bile fistulae were prepared in four rats after an overnight fast, and enzyme activities were assayed on pooled bile samples that were collected quantitatively for $4 \mathrm{~h}$. The four rats were then sacrificed, and enzyme activities were assayed on $\mathrm{E}$ - and $\mathrm{N}$-fractions of liver homogenates. All assays were done in duplicate.

* Milliunits of activity per $4 \mathrm{~h}$, mean $\pm \mathrm{SD}$.

$\ddagger$ Units of activity per gram of liver, mean \pm SD.

$\$$ Malate dehydrogenase activity is also present in the final supernate or S-fraction of homogenates of rat liver separated by differential centrifugation into 5 fractions (9).

"Esterase activity is also present in the lysosomal or L-fraction and in the final supernate or S-fraction of homogenates of rat liver separated by differential centrifugation into 5 fractions (17).
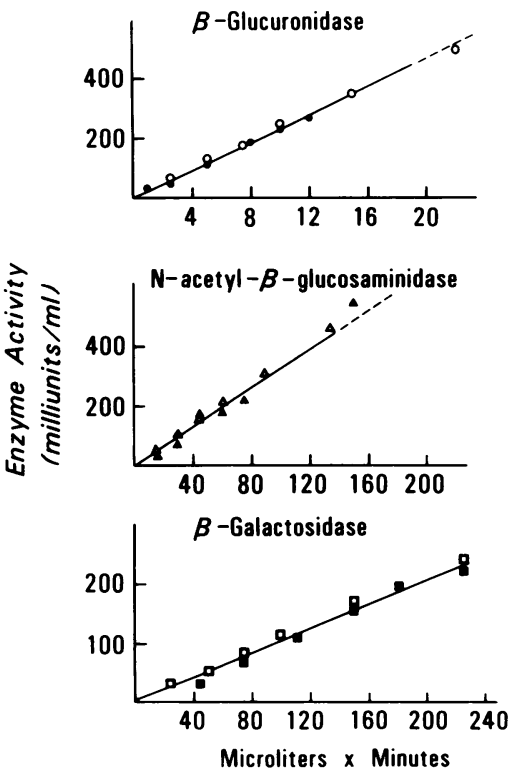

Figure 1 Kinetics of acid glycosidases in bile. Enzyme activities were determined in experiments in which time of incubation and volume of bile were each varied with the same preparation. Open symbols refer to experiments in which time was varied with a constant volume of bile. Closed symbols refer to experiments in which bile volume was varied with a constant time of incubation ( $\beta$-glucuronidase: $\bigcirc, 0.05 \mu \mathrm{l} ; \bullet, 10$ min; $N$-acetyl- $\beta$-glucosaminidase: $\triangle, 3 \mu \mathrm{l} ; \boldsymbol{\Delta}, 15$ min; $\beta$-galactosidase: $\square, 5 \mu \mathrm{l} ; \mathbf{\square}, 15 \mathrm{~min}$ ). was an inverse relationship between hepatic $N$-acetyl$\beta$-glucosaminidase activity and biliary bile acid concentration. No inhibition of hepatic $\beta$-glucuronidase or $\beta$-galactosidase by biliary bile acid was evident.

24-h acid hydrolase, protein, and bile acid output in bile. Patterns of biliary excretion of the three glycosidases, total protein, and bile acids are shown in Fig. 3 for each of six animals. In Table III, the cumulative 24-h outputs of those constituents are presented. Data in Fig. 3 show a gradual increase in biliary outputs for all three acid hydrolases, especially during the second $12 \mathrm{~h}$ of collection. The rate of excretion of $\beta$-galactosidase was consistently less than the other two glycosidases studied. However, when the cumulative biliary enzyme outputs are related to total hepatic enzyme activities, this difference is not apparent (Table III). Activity equal to $\cong 3 \%$ of the total hepatic content of each enzyme was released into bile during the 24-h period. A linear correlation $(r=0.68)$ between hepatic glycosidase activities and cumulative 24-h biliary enzyme outputs was observed (data not shown). The excretory rates of total proteins, although variable, did not appreciably change during the 24 -h collection period and averaged $\cong 19 \mathrm{mg} / 100 \mathrm{~g}$ body wt per $\mathrm{d}$ ( $\mathrm{Ta}$ ble III). This amounts to $3.0 \%$ of the total protein content of liver. The specific activity of the glycosidases in bile, therefore, increased during the 24 -h collection period and, in fact, was significantly greater by the final 


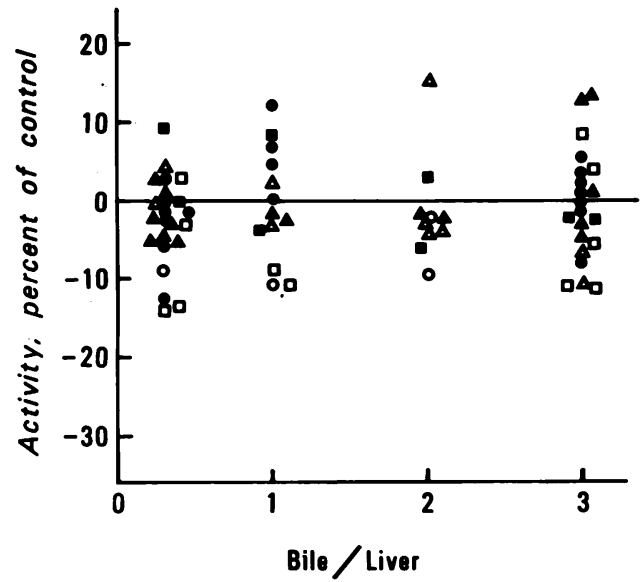

FIGURE 2 Influence of bile on activities of acid glycosidases in liver. Bile taken 1 (closed symbols) or 24 (open symbols) $\mathrm{h}$ after preparation of a bile fistula was mixed with aliquots of liver E-fractions in different proportions, and activities of $\beta$-glucuronidase $(O, \odot), \beta$-galactosidase $(\square, \square)$, and $N$-acetyl- $\beta$ glucosaminidase $(\triangle, \Delta)$ were measured immediately in the mixtures. Incubation times were 10-15 min, and initial dilutions of bile ranged from $1 / 10$ to $1 / 200$, and dilutions of liver E-fractions, from $1 / 150$ to $1 / 600$. As controls, glycosidase activities were determined separately on unmixed bile samples and liver E-fractions. Activities of mixed and unmixed samples for the three glycosidases were then compared as the percentage of activity in the mixed samples to the sum of the activities in the separate bile and liver E-fraction samples.

hour of collection than the specific activity of the three enzymes measured in liver $(P<0.05)$. Finally, biliary bile acid secretion decreased during the first $12 \mathrm{~h}$ of collection and then remained relatively constant (Fig. 3).

The biliary excretory patterns of the three glycosidases vary considerably from animal to animal (Fig. 3 ). However, the excretory rates of the enzymes in a given animal fluctuate in parallel, which suggests a coordinate relationship in their output. Table IV summarizes calculations made at each time point of ratios of excretion of one enzyme to another, to proteins, or to bile acids. Coordinancy, expressed as a coefficient of variation, is indicated by the finding that the variation in the ratios of enzymes to each other is significantly less than the variation in ratios in enzymes to proteins or to bile acids. Furthermore, the correlation coefficients of enzyme excretion relative to one another are highly significant $(P<0.01)$ in contrast to those obtained for enzyme vs. protein or enzyme vs. bile acids $(P>0.05)$.

Finally, Table $\mathrm{V}$ presents a comparison of hepatic glycosidase activity and protein content from two additional groups of bile-fistula and sham-operated rats. There were no differences between the two groups, which indicates that biliary drainage for $24 \mathrm{~h}$ does not significantly affect hepatic enzyme activity or total hepatic protein.
TABLE II

Influence of Bile Acid Composition on Activity of Acid Glycosidases

\begin{tabular}{cccc}
\hline & \multicolumn{3}{c}{ Enzyme activityt } \\
\cline { 2 - 4 } $\begin{array}{c}\text { Bile acid } \\
\text { concentration* }\end{array}$ & $\beta$-Glucuronidase & $\beta$-Galactosidase & $\begin{array}{c}N \text {-Acetyl- } \beta \text { - } \\
\text { glucosaminidase }\end{array}$ \\
\hline & $\%$ & $\%$ & $\%$ \\
17.10 & 115.4 & 83.9 & 34.0 \\
$9.4 \triangle$ & 114.8 & 96.8 & 62.0 \\
4.40 & 112.3 & 83.0 & 77.3 \\
3.80 & 109.8 & 73.3 & 79.0 \\
$3.4 \triangle$ & 109.4 & 95.9 & 85.2 \\
$1.4 \triangle$ & 110.5 & 103.3 & 97.3 \\
\hline
\end{tabular}

Duplicate $50-\mu$ l aliquots of liver E-fraction were incubated for $30 \mathrm{~min}$ at $37^{\circ} \mathrm{C}$ with $50 \mu \mathrm{l}$ of various undiluted bile samples of differing bile acid concentrations taken from two separate rats $(O$ and $\Delta)$. After dilution of the samples from $1 / 250$ to $1 / 500$, substrate was added, and the mixtures were further incubated ( $10 \mathrm{~min}, \beta$-glucuronidase and $N$-acetyl- $\beta$-glucosaminidase; $15 \mathrm{~min}, \beta$-galactosidase). Control represents the sum of enzyme activities in similarly treated $50-\mu$ l aliquots of liver E-fraction and bile incubated and assayed separately. * Micromoles per milliliter neat bile.

$\ddagger$ Percentage of control.

\section{DISCUSSION}

The main finding recorded in this paper concerns the biliary excretion of lysosomal glycosidases. Our assays, validated by appropriate kinetic studies, indicate that the excretion patterns of the three glycosidases, although variable from animal to animal, followed a parallel course in each particular animal, which suggests that the enzymes were excreted coordinately. The patterns of total protein excretion, on the other hand, were different from those of the glycosidases and varied little between animals. Finally, the three lysosomal enzymes show the same excretory rate when related to hepatic content. When averaged over $1 \mathrm{~d}$, the output of each enzyme is in the order of $3 \%$ of the liver content.

These results are strongly suggestive of selective bulk discharge of hepatic lysosomal contents in bile. It has long been known that lysosomes occupy a characteristic pericanalicular location in hepatic parenchymal cells $(2,18)$, a situation which may be important to such a phenomenon. Also supporting this view is the estimate of $3-5 \%$ of the liver content per day of a number of other lysosomal hydrolases excreted in bile given by de Duve (5) based on values obtained by Wattiaux. These estimates are possibly inexact and probably minimal approximations of hepatocyte lysosomal enzyme activity in bile because $\cong 10-15 \%$ of the total hepatic lysosomal enzyme activity originates from lysosomes of nonparenchymal cells (19) that would not be expected to secrete material into bile. In addition, 

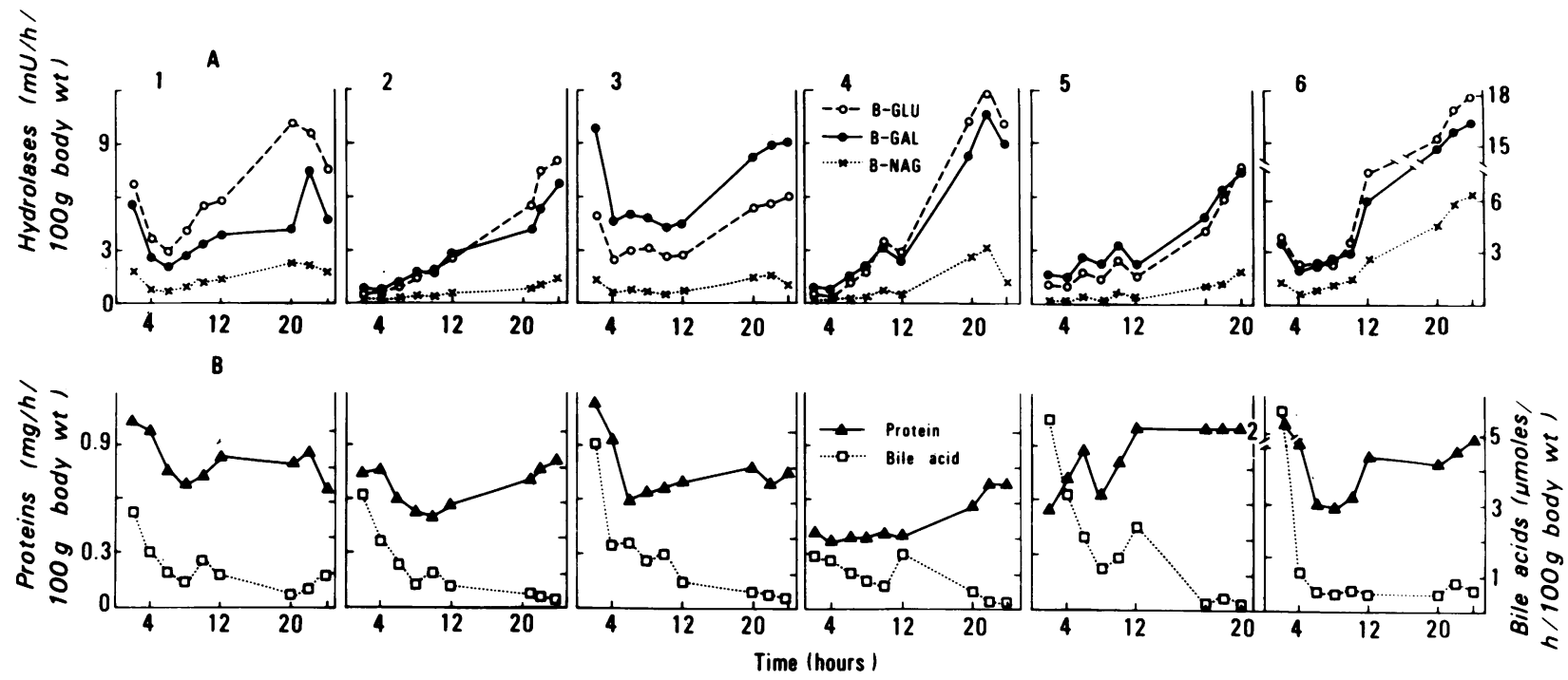

FigurE 3 24-h biliary excretion of acid hydrolases, total protein, and bile acids. (A) $\beta$-Glucuronidase $(O---O), \beta$-galactosidase $(\times \cdots \times)$, and $N$-acetyl- $\beta$-glucosaminidase $(0-0)$ outputs per $100 \mathrm{~g}$ body weight per hour for each of six rats $(1-6)$ are presented. (B) Total protein $(\boldsymbol{\Delta}-\boldsymbol{\Delta})$ and bile acid $(\square \cdots \square)$ outputs per $100 \mathrm{~g}$ body weight per hour for the same rats are shown. B-Glu, $\beta$-glucuronidase; B-gal, $\beta$-galactosidase; B-nag, $N$-acetyl- $\beta$-glucosaminidase.

the hepatocyte lysosomes that apparently discharge their contents into bile could represent a nonrandom subset of the total hepatocyte lysosomal population.

Our studies provide no direct evidence that the lysosomal protein present in bile originates from hepatocytes. Although the origin of many biliary proteins in the rat appears to be the plasma compartment (20-22), biochemical (23) and morphologic (2-4) data do suggest that discharge into bile of hepatocyte lysosomal contents, including acid hydrolases, does occur. Our studies also provide no specific information on the mechanism whereby lysosomal enzymes enter bile. Exocytosis seems the most probable explanation (1).

TABLE III

Biliary Excretion of Protein, Bile Acids, and Acid Glycosidases

\begin{tabular}{lcc}
\hline \multicolumn{1}{c}{ Glycosidases } & 24-h Output ${ }^{*} \downarrow$ & 24-h Output $\$$ \\
\hline$\beta$-Glucuronidase & $139 \pm 60$ & $3.54 \pm 1.3$ \\
$\beta$-Galactosidase & $36.9 \pm 23$ & $2.79 \pm 1.4$ \\
$N$-Acetyl- $\beta$-glucosaminidase & $126 \pm 50$ & $4.01 \pm 1.8$ \\
Protein & $19.2 \pm 5$ & $3.00 \pm 0.7$ \\
Bile acids & $24.7 \pm 6$ & - \\
\hline
\end{tabular}

Cumulative 24-h biliary outputs calculated from data on six animals presented in Fig. 3. Values are given as mean $\pm S D$.

* Expressed as milliunits, milligrams, or micromoles per $100 \mathrm{~g}$ body weight.

$\$$ Absolute.

$\S$ Percentage of total liver content.
This phenomenon has been described in other mammalian cells (24) and has recently been proposed to explain the excretion of lysosomal hydrolases in human urine (25). Furthermore, there are morphologic studies indicating exocytic discharge of lysosomal contents in bile canaliculi $(2-4,26,27)$. The significance of this morphologic evidence has been disputed (18), but alternatives to exocytosis compatible with the maintenance of cellular organization are difficult to envisage.

The physiologic significance of lysosomal discharge in bile is unclear. One obvious advantage is that it provides the hepatocytes with a disposal mechanism for undigestible residues accumulating in lysosomes (1). Whether this process could be relevant to the pathology of certain liver diseases such as Wilson's disease (28), primary biliary cirrhosis (29-31), or hemochromatosis (32-33), diseases apparently associated with accumulation of material in hepatocyte lysosomes, and whether the process can be manipulated therapeutically to accelerate removal of abnormal hepatic lysosomal deposits are matters for future research.

According to our limited data on other enzymes, smaller amounts of markers for mitochondria, endoplasmic reticulum, and cell sap seem to find their way into bile. By what mechanism they do so is unclear. Possibly, cell injury, incomplete digestion of material segregated by autophagy, and shedding of canalicular cells all contribute to the phenomenon.

The only other enzymes besides the lysosomal hydrolases that were found in bile in sizable amounts 
TABLE IV

Correlations in Biliary Excretion of Acid Hydrolases, Proteins, and Bile Acids

\begin{tabular}{lccr}
\hline & Ratio $^{*}$ & $\mathrm{CV}$ & \multicolumn{1}{c}{$r$} \\
\hline$\beta$-Glucuronidase/ $\beta$-galactosidase & $3.98 \pm 0.6$ & $0.22 \pm 0.2$ & $0.96 \pm 0.1$ \\
$\beta$-Glucuronidase/ $N$-acetyl- $\beta$-glucosaminidase & $1.03 \pm 0.3$ & $0.19 \pm 0.1$ & $0.96 \pm 0.1$ \\
$N$-Acetyl- $\beta$-glucosaminidase/ $\beta$-galactosidase & $4.32 \pm 1.4$ & $0.15 \pm 0.1$ & $0.94 \pm 0.1$ \\
$\beta$-Glucuronidase/protein & $6.50 \pm 2.3$ & $0.64 \pm 0.2$ & $0.46 \pm 0.4$ \\
$\beta$-Galactosidase/protein & $1.65 \pm 0.8$ & $0.58 \pm 0.2$ & $0.39 \pm 0.4$ \\
$N$-Acetyl- $\beta$-glucosaminidase/protein & $6.25 \pm 2.1$ & $0.54 \pm 0.2$ & $0.47 \pm 0.4$ \\
$\beta$-Glucuronidase/bile acids & $22.7 \pm 26$ & $1.32 \pm 0.4$ & $-0.48 \pm 0.3$ \\
$\beta$-Galactosidase/bile acids & $5.20 \pm 6.3$ & $1.14 \pm 0.5$ & $-0.42 \pm 0.4$ \\
$N$-Acetyl- $\beta$-glucosaminidase/bile acids & $15.6 \pm 14$ & $1.23 \pm 0.6$ & $-0.39 \pm 0.5$ \\
Bile acids/protein & $1.63 \pm 0.5$ & $0.79 \pm 0.3$ & $0.16 \pm 0.8$ \\
& &
\end{tabular}

Values were obtained from data on biliary outputs of six rats presented in Fig. 3 and are given as mean $\pm \mathrm{SD}$.

* Means of ratios calculated at each time point.

$\$$ Coefficient of variation (standard deviation/mean) of ratios for each animal.

$\$$ Correlation coefficient of biliary output with time of first constituent vs. the second as determined for each animal.

were the plasma membrane markers, $5^{\prime}$-nucleotidase and alkaline phosphodiesterase I. Similar results have been obtained by Evans et al. (20), who have suggested that the biliary excretion of these enzymes may reflect solubilization of canalicular membrane proteins by bile salts. Budding off of microvilli as a means of compensating for the addition of membrane material to the canalicular membrane by the exocytic discharge of lysosomes represents another possible mechanism.

As expected after complete interruption of the enterohepatic circulation, the excretion of bile acids fell by $\cong 80 \%$ during the first $12 \mathrm{~h}$ of collection and then remained low. Whether the late rise in lysosomal enzyme excretion is related to this change, to starvation of the animals, or to some other aspect of our experi-

TABLE V

Rat Liver Acid Glycosidase Activity and Total Protein Content

\begin{tabular}{ccc}
\hline & $\begin{array}{c}\text { Bile-fistula } \\
\text { rats }\end{array}$ & $\begin{array}{c}\text { Sham-operated } \\
\text { rats }\end{array}$ \\
\hline $\begin{array}{c}\text { Acid glycosidases* } \\
\beta \text {-Glucuronidase }\end{array}$ & $1.22 \pm 0.3$ & $1.16 \pm 0.2$ \\
$\beta$-Galactosidase & $0.33 \pm 0.1$ & $0.32 \pm 0.1$ \\
$\begin{array}{c}N \text {-Acetyl- } \beta \text {-glucos- } \\
\text { aminidase }\end{array}$ & $0.96 \pm 0.2$ & $0.83 \pm 0.2$ \\
Total protein $\ddagger$ & $210 \pm 20$ & $234 \pm 10$ \\
\hline
\end{tabular}

Liver enzyme activity and protein content were determined on five animals per group after either 24-h biliary drainage or sham operation.

* Units per gram liver, mean $\pm S D$.

t Milligrams per gram liver, mean \pm SD. mental design cannot be ascertained at this time. That this increase in assayable enzyme activity reflects primarily a true enrichment of bile with lysosomal protein, however, is supported by the increase in specific activity of lysosomal glycosidases in the late, compared with the early, bile samples.

\section{ACKNOWLEDGMENTS}

The authors wish to express their gratitude to Dr. Christian de Duve and Dr. Miklos Müller for their continued interest and advice during these studies and for their valuable suggestions in the preparation of the manuscript. We are also indebted to Cynthia Ward, Mila Koss, and Janet Carter for superb technical assistance, and to Dr. Robert Palmer of The Rockefeller University for performing bile acid analyses.

This research was supported by U. S. Public Health Service grant AG-00367.

\section{REFERENCES}

1. de Duve, C., and R. Wattiaux. 1966. Functions of lysosomes. Annu. Rev. Physiol. 28: 435-492.

2. Bruni, C., and K. Porter. 1965. The fine structure of the parenchymal cell of the normal rat liver. I. General observations. Am. J. Pathol. 46: 691-756.

3. Bradford, W. D., J. G. Elchlipp, A. U. Arstila, B. F. Trump, and T. D. Kinney. 1969. Iron metabolism and cell membranes. Relation between ferritin and hemosiderin in bile and biliary excretion of lysosomes contents. Am. J. Pathol. 56: 201-228.

4. Sknitka, T. K. 1965. Pinocytic labeling of liver-cell lysosomes with colloidal gold. Observations on the uptake of the marker, and its subsequent discharge into bile canaliculi. Fed. Proc. 24: 556. (Abstr.)

5. de Duve, C. 1963. The lysosome concept. In Ciba Foundation Symposium on Lysosomes. A. V. S. de Reuck and M. P. Cameron, editors. Little, Brown and Co., Boston. $1-31$. 
6. Holdsworth, G., and R. Coleman. 1975. Enzyme profiles in mammalian bile. Biochim. Biophys. Acta. 389: 47-50.

7. Toyoda, S., Y. Eto, and K. Aoki. 1977. Bile lysosomal enzymes: characteristics and pathological significance for various hepatobiliary disorders. Clin. Chim. Acta. 79: 291-298.

8. Eaton, D. L., and C. D. Klaasen. 1976. Effects of acute administration of taurocholic and taurochenodeoxycholic acid on biliary lipid excretion in the rat. Proc. Soc. Exp. Biol. Med. 151: 198-202.

9. de Duve, C., B. C. Pressman, R. Gianetto, R. Wattiaux, and F. Appelmans. 1955. Tissue fractionation studies. 6 . Intracellular distribution patterns of enzymes in rat liver tissue. Biochem. J. 60: 604-617.

10. Peters, T. J., M. Müller, and C. de Duve. 1972. Lysosomes of the arterial wall. I. Isolation and subcellular fractionation of cells from normal rabbit aorta.J. Exp. Med. 136: $1117-1139$.

11. Beaufay, H., A. Amar-Costesec, E. Feytmans, D. ThinesSempoux, M. Wibo, M. Robbi, and J. Berthet. 1974. Analytical study of microsomes and isolated subcellular membranes from rat liver. I. Biochemical methods.J. Cell Biol. 61: 188-200.

12. Avruch, J., and D. F. H. Wallach. 1971. Preparation and properties of plasma membrane and endoplasmic reticulum fragments from isolated rat fat cells. Biochim. Biophys. Acta. 233: 334-339.

13. Dupourque, D., and E. Kun. 1969. Cytoplasmic and mitochondrial malate dehydrogenases from beef kidney. Methods Enzymol. 13: 116-122.

14. Reeves, W. J., and G. M. Femognari. 1966. L-Lactic dehydrogenase: heart $\left(\mathrm{H}_{4}\right)$. Methods Enzymol. 9: 288-289.

15. Leighton, F., B. Poole, H. Beaufay, P. Baudhuin, J. W. Coffey, S. Fowler, and C. de Duve. 1968. The large-scale separation of peroxisomes, mitochondria, and lysosomes from the livers of rats injected with Triton WR-1339.J. Cell Biol. 37: 482-513.

16. Iwata, T., and K. Yamasaki. 1964. Enzymatic determination and thin-layer chromatography of bile acids in blood. J. Biochem. (Tokyo). 56: 424-431.

17. LaRusso, N. F., D. G. Lindmark, and M. Müller. 1978. Biliary and renal excretion, hepatic metabolism and hepatic subcellular distribution of metronidazole in the rat. Biochem. Pharmacol. 27: 2247-2254.

18. Novikoff, A. B. 1973. Lysosomes: a personal account. In Lysosomes and Storage Diseases. H. G. Hers and F. Van Hoof, editors. Academic Press, Inc., New York. 2-41.

19. Muntke-kaas, A. C., T. Berg, and R. Seljelid. 1976. Dis- tribution of lysosomal enzyme in different types of rat liver cells. Exp. Cell Res. 99: 146-154.

20. Evans, W. H., T. Kremmer, and J. G. Culvenor. 1976. Role of membranes in bile formation. Comparison of the composition of bile and a liver bile-canalicular plasma membrane subfraction. Biochem. J. 154: 589-595.

21. Lemaitre-Coelho, I., G. D. F. Jackson, and J-P. Vaerman. 1977. Rat bile as a convenient source of secretory IgA and free secretory component. Eur. J. Immunol. 7: 588590 .

22. Mullock, B. M., and R. H. Hinton. 1978. The relation of bile proteins to serum and liver plasma membrane. Biochem. Soc. Trans. 6: 274-276.

23. Mullock, B. M., M. Dobrota, and R. H. Hinton. 1978. Sources of the proteins of rat bile. Biochim. Biophys. Acta. 543: 497-507.

24. Dingle, J. T. 1969. The extracellular secretion of lysosomal enzymes. In Lysosomes in Biology and Pathology. J. T. Dingle and H. B. Fell, editors. North Holland Publishing Co., Amsterdam. 2: 421-436.

25. Paigen, K., and J. Peterson. 1978. Coordinancy of lysosomal enzyme excretion in human urine. J. Clin. Invest. 61: $751-762$.

26. Glinsmann, W. H., and J. L. E. Ericsson. 1966. Observations on the subcellular organization of hepatic parenchymal cells. II. Evolution of reversible alterations induced by hypoxia. Lab. Invest. 15: 762-777.

27. Kerr, J. F. R. 1970. Liver cell defaecation: an electronmicroscope study of the discharge of lysosomal residual bodies into the intercellular space.J. Pathol. 100: 99- 103.

28. Scheinberg, I. H., and I. Sternlieb. 1965. Wilson's disease. Annu. Rev. Med. 16: 119-134.

29. Fleming, C. R., E. R. Dickson, A. H. Baggenstoss, and J. T. McCall. 1974. Copper and primary biliary cirrhosis. Gastroenterology. 67: 1182-1187.

30. Owen, C. A., E. R. Dickson, N. P. Goldstein, A. H. Baggenstoss, and J. T. McCall. 1977. Hepatic subcellular distribution of copper in primary biliary cirrhosis. Comparison with other hyperhepatocupric states and review of the literature. Mayo Clin. Proc. 52: 73-80.

31. Sipponen, P. 1976. Orcein positive hepatocellular material in long-standing biliary diseases. II. Ultrastructural studies. Scand. J. Gastroenterol. 11: 553-557.

32. Barry, M. 1974. Progress report: iron and the liver. Gut. 15: 324-334.

33. Peters, T. J., and C. A. Seymour. 1976. Acid hydrolase activities and lysosomal integrity in liver biopsies from patients with iron overload. Clin. Sci. Mol. Med. 50: 7578. 